\title{
Behavior of Ti/HA in Saliva at Different Temperatures as Restorative Materials
}

\author{
Rana Afif Anaee ${ }^{1}$
}

Received: 27 November 2015/Revised: 9 February 2016/Accepted: 26 February 2016/Published online: 10 March 2016

(C) Springer International Publishing Switzerland 2016

\begin{abstract}
Titanium and hydroxyapatite (HA) are wellknown materials applied as biomaterials. Ti shows good mechanical properties and corrosion resistance, whereas HA possesses excellent biocompatibility and bioactivity but weak mechanical properties. The combination of the Ti and HA properties is expected to produce good corrosion resistance. Corrosion behavior of $\mathrm{Ti} / \mathrm{HA}$ as composite (70Ti/30HA) and functionally graded material (Ti/HA FGM with five layers) has been investigated in saliva at $\mathrm{pH}$ 4.4 at five temperatures $10,20,30,40$, and $50{ }^{\circ} \mathrm{C}$ to use it as restorative material. There is reason for concern about the weak ceramic/metal bond and the integrity of this interface over a long-term performance under functional loading, therefore Ti/HA as FGM was fabricated to get good cohesive force between metal (Ti) and ceramic (HA) through the graduated layers. The corrosion results of $\mathrm{Ti} /$ HA materials were compared with that of pure Ti. The X-ray diffraction patterns and SEM of the composite showed that the HA decomposed and formed secondary phases which have biocompatibility in human body. These phases are mainly $\mathrm{Ca}_{5}\left(\mathrm{PO}_{4}\right)_{3}(\mathrm{OH}), \mathrm{Ti}_{4} \mathrm{P}_{3}, \mathrm{CaO}, \mathrm{Ca}_{4}$ $\mathrm{O}\left(\mathrm{PO}_{4}\right)_{2}$, and $\beta$-TCP. The results showed that the corrosion rate of Ti/HA as composite and FGM was lower than that for pure $\mathrm{Ti}$ due to the role of HA which forms phases that reduce the reactivity of titanium to dissolve in saliva over experimental temperatures. Also, the data of polarization resistance for $\mathrm{Ti} / \mathrm{HA}$ materials were higher than that for pure $\mathrm{Ti}$ in saliva. Biocompatibility test showed that Ti/HA materials gave good absorption to culture cells, and
\end{abstract}

Rana Afif Anaee

dr.rana_afif@yahoo.com

1 Department of Materials Engineering, University of Technology, Baghdad, Iraq functionally graded material had better absorbance than composite.

Keywords Biomaterials · Dental applications · Titanium $\cdot$ Hydroxyapatite

\section{Introduction}

The mouth is the portal entry of the human body. It is also the habitat of microbial species that are kept wet by saliva. Teeth and other materials in oral cavity are subject to the most extreme temperature variations, enduring temperatures as low as $0{ }^{\circ} \mathrm{C}$ to hot foods and beverages $\left(\sim 60{ }^{\circ} \mathrm{C}\right)$.

Dental treatment involving biomaterials will alter the mechanical, physiological, and chemical conditions in the oral cavity. The degree of change depends on the size and quality of the restoration inserted, which in turn, will affect the microbiology of the oral cavity. All surfaces in the oral cavity are covered by a pellicle of glycoproteins from saliva within seconds after cleaning [1,2]. Microorganisms are able to adhere to this layer and form biofilms organized as a consortium of bacteria, virus, and fungi.

By inserting foreign bodies such as dental restorations, new niches appear for the microorganisms. Such niches create areas promoting biofilm accumulation with a pathological potential. Increased numbers of microorganisms with a pathological ability will increase the risk of developing disease.

As it has been the case in orthopedics for almost two decades, we now have alternatives dentistry. Metal-free and metal alloy-free structures are available for teeth replacement, from the implant embedded in bone to the visible crown in the oral cavity. Zirconia (ceramic) dental implants and all types of all-ceramic restoration (crown, 
bridge, retentive bars, etc.) are available. Furthermore, bioceramics accumulate very little biofilm if at all thus reducing bacteria habitat, multiplication, and by-products. The limitations of ceramic materials are their low tensile strength and fracture toughness. Their use in bulk form is therefore limited to functions in which only compressive loads are applied. Results of ex vivo push-out tests indicate that the ceramic/metal bond fails before the integration of the ceramic/tissue bond because of the weak link in the system [3].

Dental restorations affect the composition of the biofilm in many ways. There will always be steps, gaps or groves between tooth and restoration. These will complicate mechanical biofilm removal and alter the chemical balance in the biofilm $[4,5]$. Restorations differ from enamel with regard to surface roughness, surface energy, and chemical composition [4-8].

Numerous researchers studied the degradation of $\mathrm{Ti}$ as biomaterial in artificial biological environment [9-16]. Others highlighted the materials which are used in dental applications by finding alternative materials with better properties. They tried to discover many materials as alternative biomaterials by combining metals and ceramic materials [17-29].

Although metals exhibit high strength and toughness, they are susceptible to chemical and electrochemical degradation. However, the limitations of ceramic materials are their low tensile strength and fracture toughness. Therefore, we attempted to combine metallic material (Ti) and ceramic material (HA) as composite with weight percents 70:30, respectively, and functionally graded material with five layers. Corrosion behavior of these materials has been studied in saliva a over wide range of temperatures $\left(10-50^{\circ} \mathrm{C}\right)$ which simulate the temperature of many foods and beverages.

\section{Experimental Procedure}

Powder metallurgy method was used to fabricate Ti/HA as composite and functionally graded materials. In composite, weight percents of $\mathrm{Ti}$ and $\mathrm{HA}$ were 70 and $30 \mathrm{wt} \%$ respectively. While in functionally graded material, five layers were prepared with composition as shown in Table 1. Metallic and ceramic powders were weighted by sensitive balance type (BEL), which was estimated by the following formula:

$w_{\mathrm{L}}=\rho_{\mathrm{L}} \times V_{\mathrm{L}} \times V_{1}$,

where $w_{\mathrm{L}}$ and $\rho_{\mathrm{L}}$ are weight and density of powder layer, $V_{\mathrm{L}}$ is layer volume, and $V_{1}$ is volume fraction.

Pure Ti with purity $98.5 \%$ and average particle size $42 \mu \mathrm{m}$ obtained from (Fluka Chemie AG. CH-9470 Buchs)
Table 1 Chemical composition of layers in Ti/HA FGM

\begin{tabular}{lll}
\hline No. of layer & Thickness $(\mathrm{mm})$ & Composition $(\%)$ \\
\hline 1st layer & 3 & 100Ti \\
2nd layer & 2.5 & 75Ti-25HAP \\
3rd layer & 2 & 50Ti-50HAP \\
4th layer & 1.5 & 25Ti-75HAP \\
5th layer & 1 & 100HAP \\
\hline
\end{tabular}

was used in fabrication. Hydroxyapatite (HA) with purity $99.8 \%$ and average particle size $42 \mu \mathrm{m}$ obtained from (India) was used as ceramic material. Wet mixing was used by Ball Mills type PM200 with rotational speed of $300 \mathrm{rpm}$ for $1 \mathrm{~h}$. Cold uniaxial pressing in double action dies has been practiced with $50 \mathrm{~mm}$ height, $12 \mathrm{~mm}$ interior diameter, and $32 \mathrm{~mm}$ outer diameter.

Sintering process was achieved in quartz tube which was placed in furnace type (Thermco-model mini brute 201) at $1000{ }^{\circ} \mathrm{C}$ for $2 \mathrm{~h}$.

All X-ray diffraction tests were carried out on X-ray generator with $\mathrm{Cu} \mathrm{K} \alpha$ radiation at $40 \mathrm{~kW}$ and $20 \mathrm{~mA}$. The target used in the $\mathrm{X}$-ray tube was $\mathrm{Cu}$, therefore $\lambda_{\mathrm{Cu}}=1.54060^{\circ} \mathrm{A}$ and was operated at scanning speed of $5^{\circ}$ $(2 \theta)$ per minute.

Scanning electron microscope was used for functionally graded material and composite at 20,000× (Hitachi S4700 EDAX ApolloX Genesis software).

Potentiostatic measurements were carried out using WINKING MLab 200 Potentiostat from Bank Elektronik with electrochemical standard cell. Electrochemical measurements were performed with a potentiostat by SCI electrochemical software at a scan rate $5 \mathrm{mV} / \mathrm{s}$. Polarization experiments were started when the rate at which open circuit potential $\left(E_{\mathrm{ocp}}\right)$ changed was less and more $200 \mathrm{mV}$. SCE was used as reference electrode and Pt as counter electrode, while working electrodes were pure $\mathrm{Ti}, \mathrm{Ti} / \mathrm{HA}$ as composite and Ti/HA as FGM.

The electrolyte reference used was modified Fusayama artificial saliva [30], which closely resembles natural saliva, with composition of $(0.4 \mathrm{~g} / \mathrm{l} \mathrm{KCl}, 0.4 \mathrm{~g} / \mathrm{l} \mathrm{NaCl}$, $0.906 \mathrm{~g} / 1 \mathrm{CaCl}_{2} \cdot 2 \mathrm{H}_{2} \mathrm{O}, 0.69 \mathrm{~g} / 1 \mathrm{NaH}_{2} \mathrm{PO}_{4} \cdot 2 \mathrm{H}_{2} \mathrm{O}, 0.005 \mathrm{~g} / \mathrm{l}$ $\mathrm{Na}_{2} \mathrm{~S} \cdot 9 \mathrm{H}_{2} \mathrm{O}$, and $1 \mathrm{~g} / \mathrm{l}$ urea). Lactic acid was added to adjust the $\mathrm{pH}$ of the solution equal to 4.4 [31].

To achieve biocompatibility test, L929 fibroblast cell culture was used in culture media ATCC - formulated Eagle's minimal essential medium supplemented with $10 \%(\mathrm{v} / \mathrm{v})$ horse serum and Penn Strep (200 U/ml). Counting Cells were performed using vital dye, trypan blue, to determine viable versus nonviable cells (the dye is excluded from viable cells). Determination of trypan blue viability is useful when seeding cells into culture that have 
just been thawed from cryopreservation or when performing subcultures. If only the total cell number is desired, as may be the case for the end point of an experiment, the trypan blue steps may be omitted. Before beginning the procedure, obtain a clean hemocytometer with cover slip and other materials required for the operation.

\section{Results and Discussion}

\subsection{Characterization of Fabricated Materials}

The XRD patterns of started powders Ti and HA are shown in Fig. 1 with $h k l$ values, these patterns are in agreement with titanium (JCPDS 44-1294 Card) and HA (JCPDS 09-0432 card). The XRD patterns of fabricated Ti/HA as composite and FGM are shown in Figs. 2 and 3. These figures indicate the phases which are formed between $\mathrm{Ti}$ and HA. The HA partially decomposes into $\mathrm{CaO}$ and $\mathrm{Ca}_{4} \mathrm{O}\left(\mathrm{PO}_{4}\right)_{2}$ (TTCP), while some Ti converts to $\mathrm{Ti}_{2} \mathrm{O}$, as well as, when $\mathrm{Ti}_{4} \mathrm{P}_{3}$ at the Ti/HA interfaces are also formed [32].

The XRD patterns showed the combination of HA spectrum and titanium. Some of the phases observed in the sintered part are $\mathrm{Ca}_{5}\left(\mathrm{PO}_{4}\right)_{3}(\mathrm{OH})$ (JCPDS 34-0010 Card), $\mathrm{Ti}_{4} \mathrm{P}_{3}$ (JCPDS 22-0944 Card), CaO (JCPDS 03-1123 Card), $\mathrm{Ca}_{4} \mathrm{O}\left(\mathrm{PO}_{4}\right)_{2}$ (JCPPDS 25-1137 Card), and $\beta$-TCP (JSPDS 09-0169 card).

In the XRD patterns of FGM and composite, samples did not show the main peak of HA, which suggests that HA was decomposed. Also titanium oxide phases are observed, resulting from the interaction of $\mathrm{Ti}$ with $\mathrm{O}$ ions from the bulk HA. These phase formations are a common phase of interaction between $\mathrm{HA}$ and $\mathrm{Ti}$, as reported $[19,33]$.
The phases formed between Ti and HA more clearly appear in SEM images for Ti/HA as composite and FGM as shown in Figs. 4 and 5, respectively. The sintered composites exhibit a reasonably homogenous distribution of both constituents. As a result of the mixing process, the HA has formed larger agglomerates than those observed in the loose powder which resulted in the two phase distribution. HA zones with varied dimensions can be observed and dispersed in a matrix of Ti grains. Darker zones disseminated in the Ti matrix can also be observed, which correspond mainly to the porosity that has not been eliminated during the sintering step. The soft agglomerated ultra-fine HA particles break up easily during compaction due to high uniform pressure [32].

The hexagonal structure of $\alpha$-Ti appears in the first layer and it had an irregular particle shape. Also, the unit cell of biologic apatite has the shape of a stubby rhombic prism. It is clear in fifth layer as shown in Fig. 5. The morphology of the middle layers has different structures compared with the first and fifth layers. Several microcracks and microporosity are often seen on the scanning electron micrographs of these layers.

It can be seen that the agglomerates of the starting materials were broken down and reduced to smaller particulates for Ti and HA. In both cases, the presence of small agglomerates of HA on titanium particles can also be observed [19].

Fine particles can be seen attached to the surface of titanium while agglomerates lie in the form of layers. In general, the mixture with nanometric HA presents fewer agglomerates and a more even distribution of calcium phosphate. Agglomerate size may also play a role in the dispersion and size of HA particulates during milling. The microstructure of materials also consisted of tiny pores which always exist on grain boundaries and are enclosed by several grains in the vicinity.
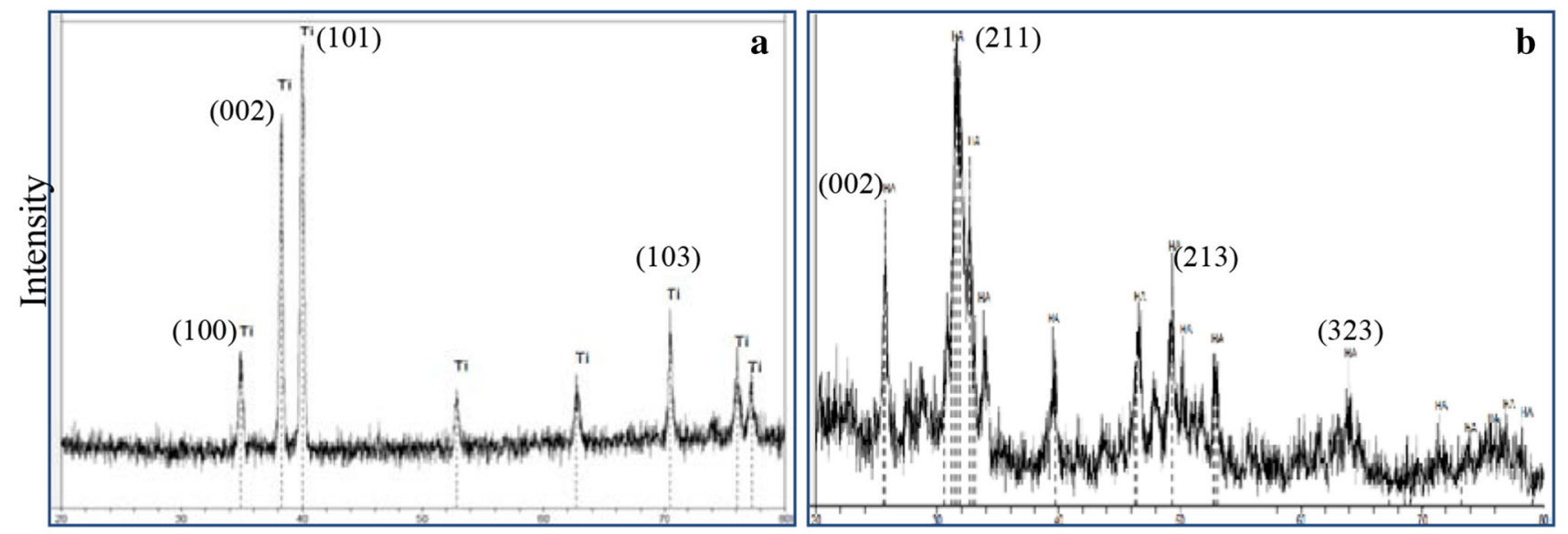

Fig. 1 XRD pattern of Ti (a) and HA (b) powders 


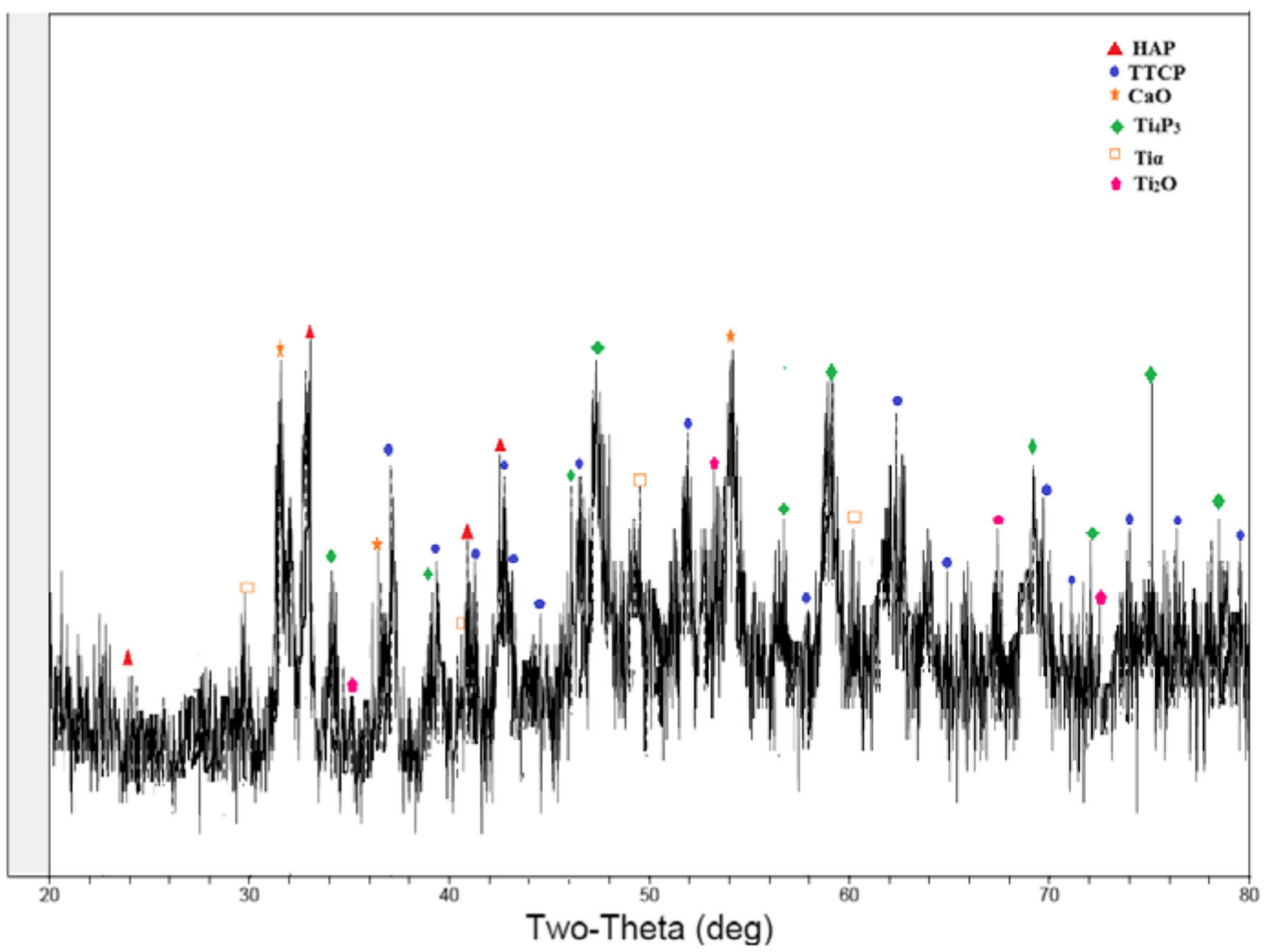

Fig. 2 XRD pattern of Ti/HA as composite

\subsection{Corrosion Behavior}

Tafel plots of pure $\mathrm{Ti}, \mathrm{Ti} / \mathrm{HA}$ as composite, and Ti/HA as functionally graded material (FGM) in artificial saliva at five different temperatures are shown in Figs. 6, 7, and 8. These figures illustrate the cathodic and anodic regions, where reduction of hydrogen and dissolution of titanium can occur respectively as follows:

$2 \mathrm{H}^{+}+2 \mathrm{e} \rightarrow \mathrm{H}_{2} \uparrow$ At cathode,

$\mathrm{Ti} \rightarrow \mathrm{Ti}^{4+}+4 \mathrm{e}$ At anode.

In order to study the electrochemical behavior of titanium systems in condition close to those of clinical reality, it is absolutely necessary to have oxidized layers characteristics of stationary state. In the case of $\mathrm{Ti}$, the good corrosion resistance results from the formation of very stable, continuous, highly adherent, and protective oxide film on metal surface. The nature, composition, and thickness of the protective surface oxides that form on titanium alloys depend on environmental conditions. As is widely known, the Pourbaix (potential-pH) diagram for titanium-water system at $25^{\circ} \mathrm{C}$ [34] depicts the wide regime over which the monoxide, trioxide, and dioxide of titanium are predicted to be stable, based on thermodynamic (free energy) consideration.

During anodic or cathodic polarization, electron and ion transfer reactions will take place. Many reactions can occur with titanium as follows:

$\mathrm{Ti}+\mathrm{H}_{2} \mathrm{O} \rightarrow \mathrm{TiO}+2 \mathrm{H}^{+}+2 \mathrm{e}$,

$2 \mathrm{Ti}+3 \mathrm{H}_{2} \mathrm{O} \rightarrow \mathrm{Ti}_{2} \mathrm{O}_{3}+6 \mathrm{H}^{+}+6 \mathrm{e}$,

$\mathrm{Ti}_{2} \mathrm{O}_{3}+4 \mathrm{OH}^{-} \rightarrow 2 \mathrm{TiO}(\mathrm{OH})_{2}+\mathrm{H}_{2} \mathrm{O}+2 \mathrm{e}$,

$2 \mathrm{TiO}(\mathrm{OH})_{2} \rightarrow \mathrm{TiO}_{2}+2 \mathrm{H}_{2} \mathrm{O}$,

$\mathrm{TiO}_{2} \cdot n \mathrm{H}_{2} \mathrm{O} \rightarrow \mathrm{TiO}(\mathrm{OH})_{2(\mathrm{aq})}$.

The data of corrosion are listed in Table 2 obtained by Tafel extrapolation method. These data indicate that the corrosion potential $\left(E_{\text {corr }}\right)$ varied for pure $\mathrm{Ti}$ and $\mathrm{Ti} / \mathrm{HA}$ materials with varied temperatures. This may be attributed to variation in cathodic and anodic sites on materials surface. Corrosion current densities of Ti/HA materials was lower than for pure Ti, and the FGM has the lowest current densities $\left(i_{\text {corr }}\right)$. The current densities increased with increasing temperature due to increasing ion and electron transfer. Generally, cathodic and anodic Tafel slopes 


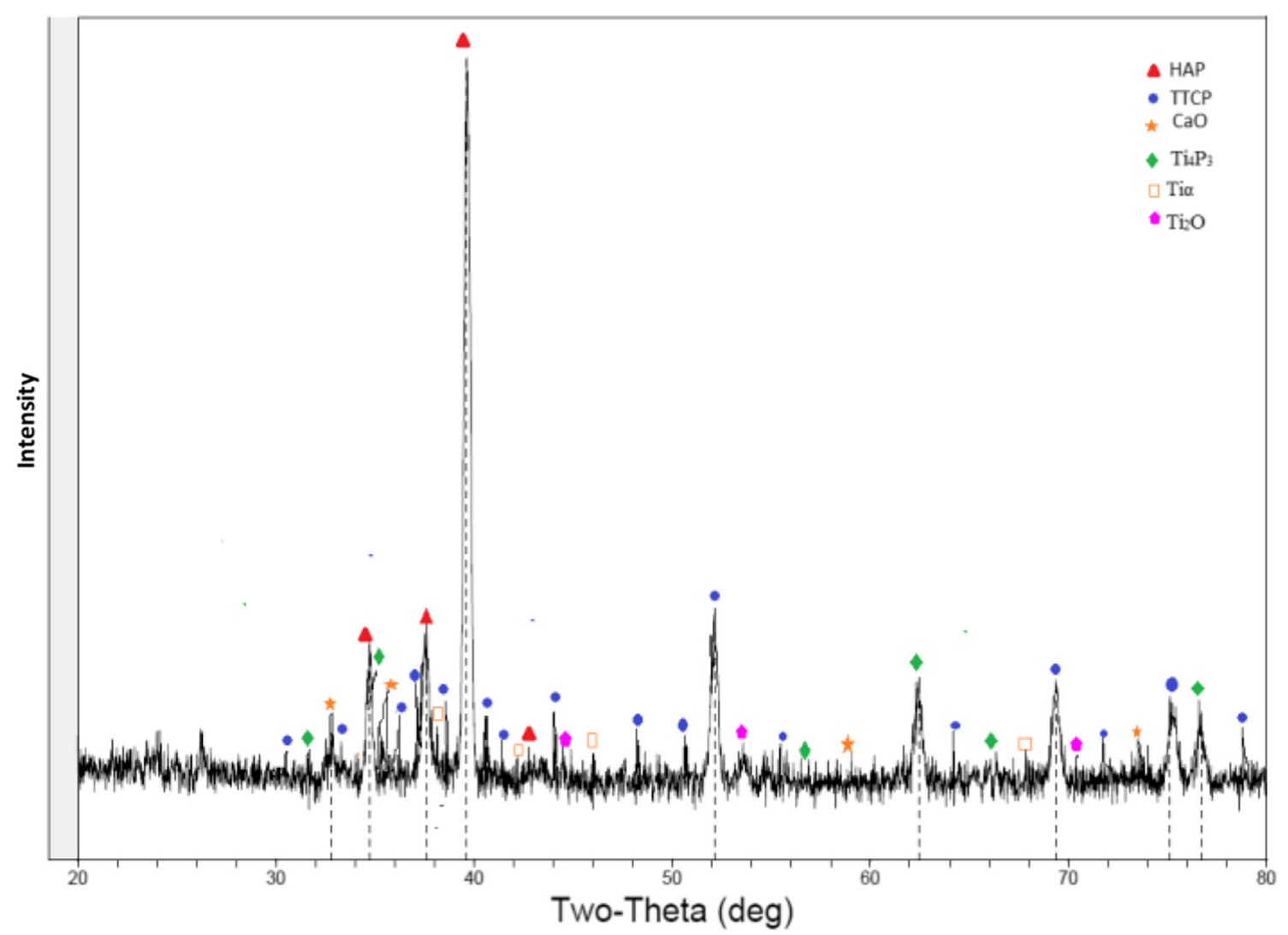

Fig. 3 XRD pattern of Ti/HA as FGM

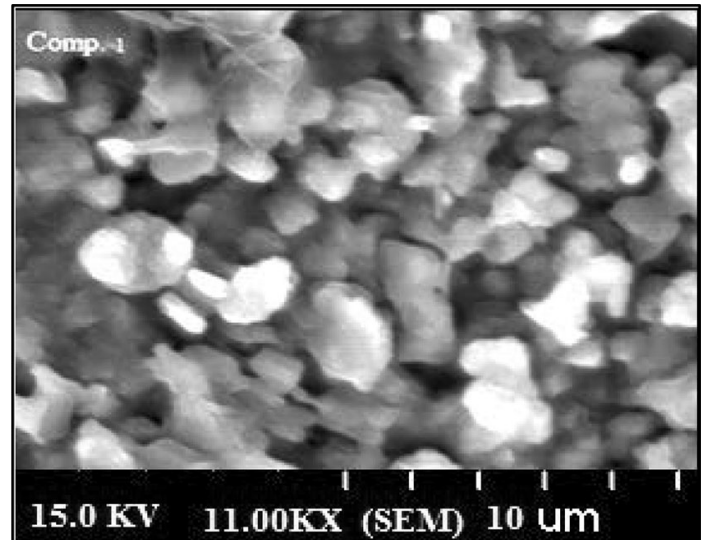

Fig. 4 SEM image of Ti/HA as composite

decrease for Ti/HA compared with pure Ti due to depolarization, and the rate of reaction is controlled by only activation polarization because of consumption of oxygen to form stable oxide layers.

The polarization resistance $R_{\mathrm{p}}$ can be calculated according to Stern-Geary equation using the data of Tafel slopes and corrosion current densities as follows [35, 36]:
$R_{\mathrm{p}}=\left(\frac{\mathrm{d} E}{d i}\right)_{i=0}=\frac{b_{\mathrm{a}} b_{\mathrm{c}}}{2.303\left(b_{\mathrm{a}}+b_{\mathrm{c}}\right) i_{\mathrm{corr}}}$,

where $b_{\mathrm{a}}$ and $b_{\mathrm{c}}$ are anodic and cathodic Tafel slopes, respectively.

The data of $R_{\mathrm{p}}$ which are calculated according to above equation are listed in Table 2. These data indicate, in general, the higher resistance for Ti/HA than pure Ti. The rate of corrosion $\left(C_{\mathrm{R}}\right)$ also can be calculated in (mpy) according to the following equation [37]:

$C_{\mathrm{R}}=0.13 \times i_{\text {corr }} \times \frac{e}{\rho}$,

where $i_{\text {corr }}$ is corrosion current density in $\mu \mathrm{A} / \mathrm{cm}^{2}, e$ and $\rho$ are the equivalent weight and density of material respectively. The data of corrosion rate showed that the Ti/HA materials had lower rate than pure Ti. The more resistance for Ti/HA materials is in good agreement with the results of corrosion of currently fabricated materials in Ringer's solution at $37{ }^{\circ} \mathrm{C}$ [38]. The current results are agreement with the increasing corrosion resistance of HA coated on metals [24].

Material combinations with limited or no history of successful use in orthopedic implants must be determined 


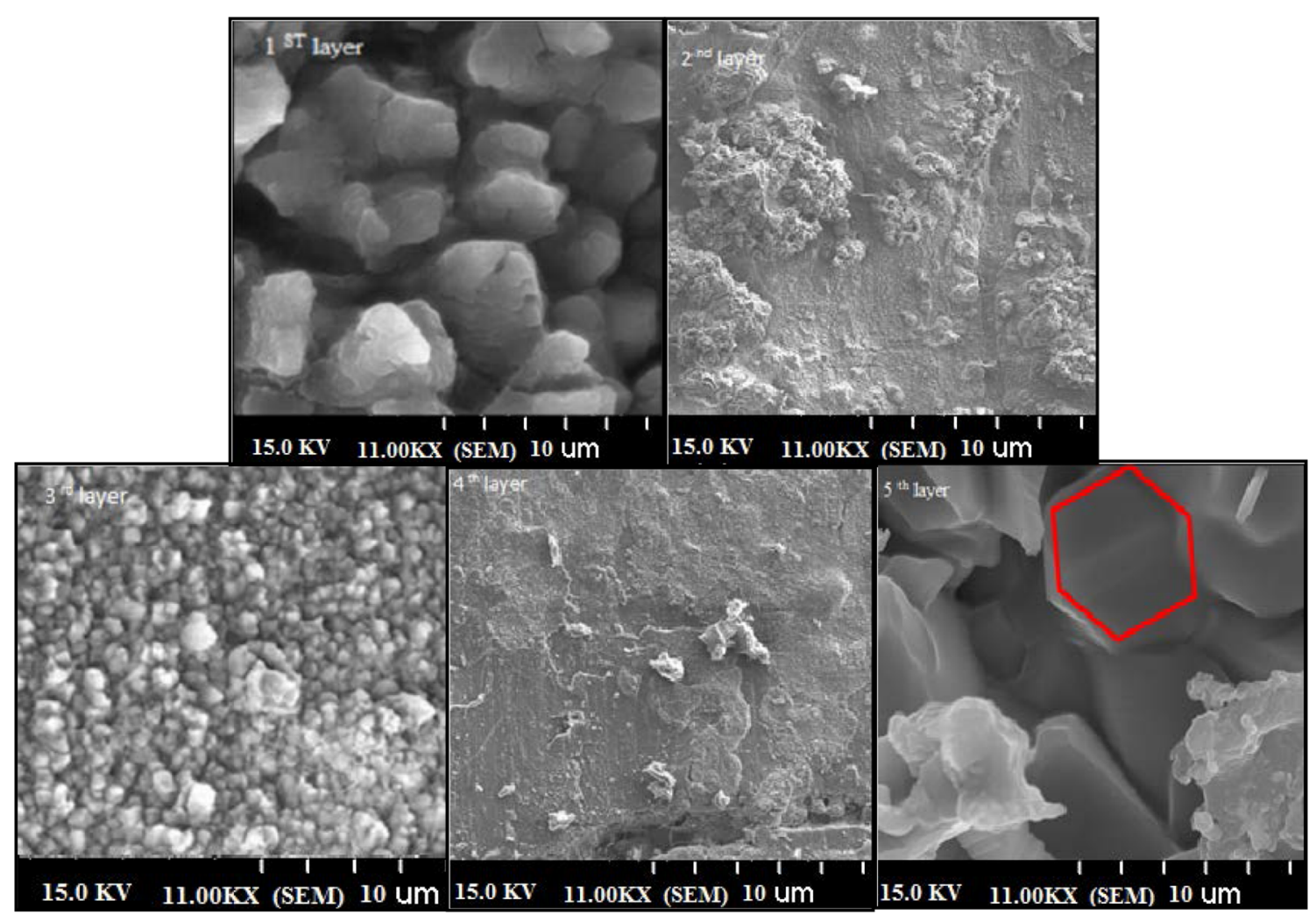

Fig. 5 SEM images of five layers in Ti/HA as FGM

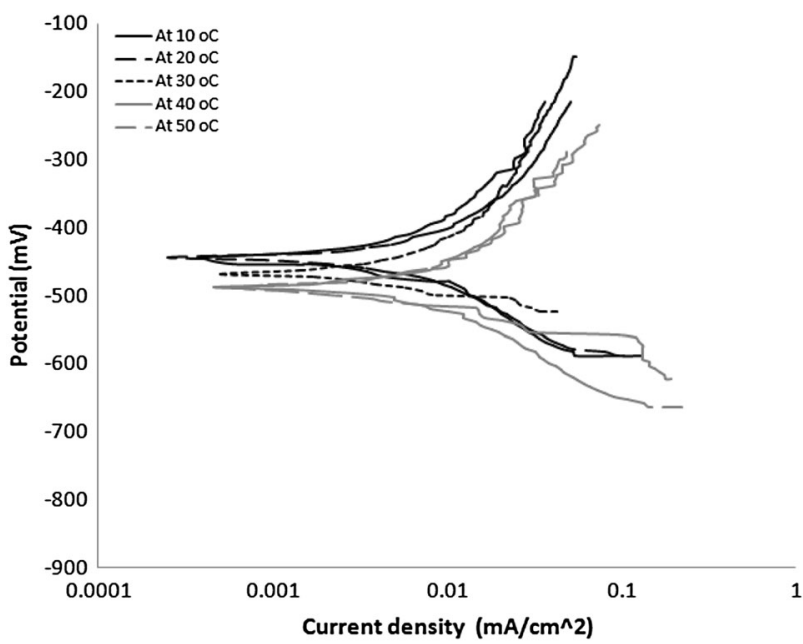

Fig. 6 Tafel plots of pure $\mathrm{Ti}$ in saliva at different temperatures

to exhibit an acceptable biological response through the tissue response to the modified surface which is addressed by the following: amount of tissue apposition, depth of tissue in growth, and the strength of the junction between the bone or bone cement and implant surface in bending, shear, tension, or torsion.

The cyclic polarization curves recorded for pure $\mathrm{Ti}$ and $\mathrm{Ti} / \mathrm{HA}$ materials in artificial saliva at $50{ }^{\circ} \mathrm{C}$ are presented in

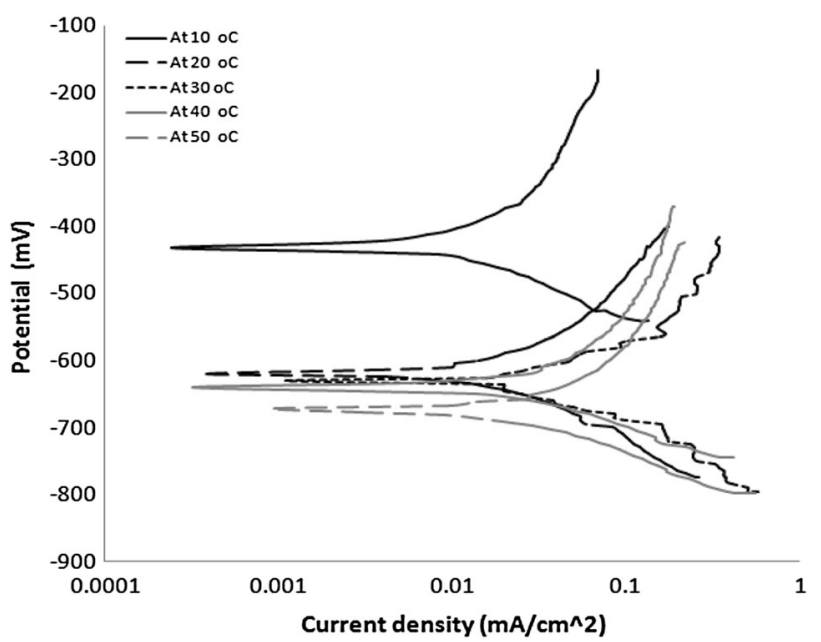

Fig. 7 Tafel plots of Ti/HA as composite in saliva at different temperatures

Fig. 9. These curves are in good agreement with that obtained by Hamid and Majid [39]. As shown in Fig. 9, no breakdown potential is observed for the pure $\mathrm{Ti}$ and $\mathrm{Ti} / \mathrm{HA}$ materials up to $1 \mathrm{~V}$ applied potential. No hysteresis loop is observed also. Cyclic polarizations of pure $\mathrm{Ti}$ and $\mathrm{Ti} / \mathrm{HA}$ are similar. This can be ascribed to the fact that the passive films formed on these materials are the same in nature, 


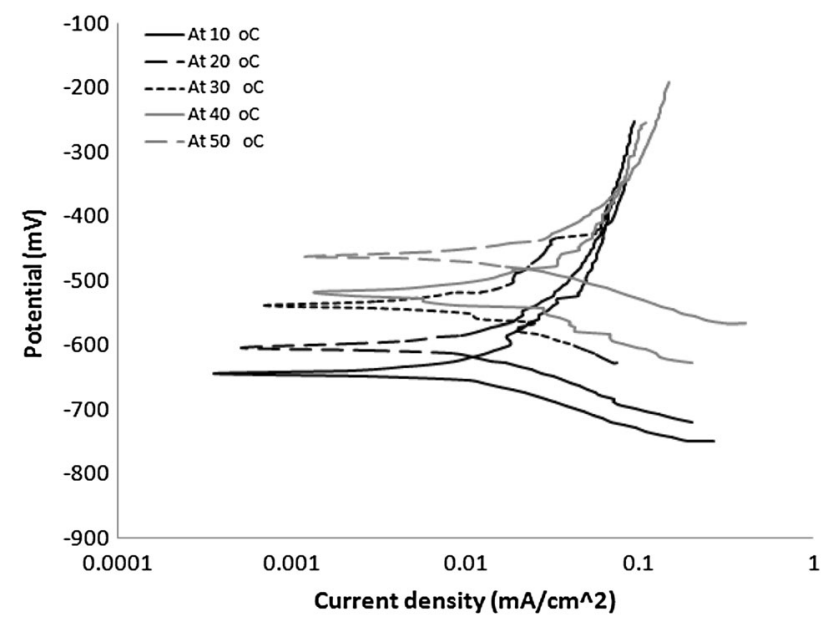

Fig. 8 Tafel plots of Ti/HA as FGM in saliva at different temperatures

essentially consisting of $\mathrm{TiO}_{2}$ [40]. Usually passive films form a barrier, but under special conditions and immediate increase of local conductivity, a passivity breakdown is observed [41]. The cyclic polarization of Ti/HA as composite and FGM was observed at lower current density and nobler potentials.

\subsection{Biocompatibility}

Biocompatibility is the degree to which biomaterials result in a tissue reaction. The more biocompatible a metal, the less negative tissue reaction occurs. For example,

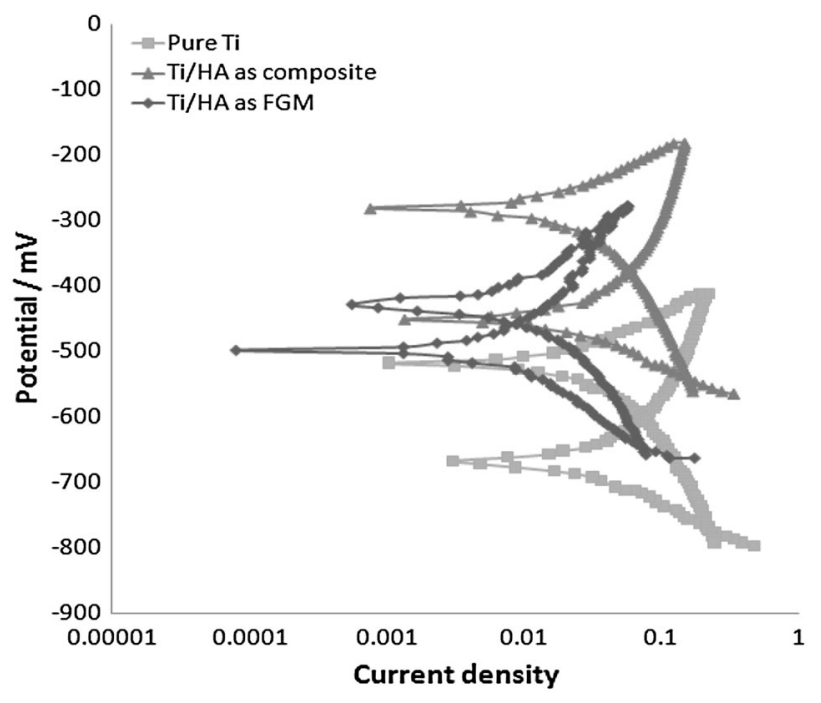

Fig. 9 Cyclic polarization in saliva at $50{ }^{\circ} \mathrm{C}$

Osseointegration may be wanted in one case but not in another. In the latter it would be a negative reaction. It is known that pure Ti has good biocompatibility. The fabricated Ti/HA materials also show the good absorbance by culture cell equal to 0.8445 and 3.1745 for Ti/HA as composite and FGM respectively.

The biocompatibility of a material for implants has to be weighed against its mechanical properties. This is always a compromise. There is no perfect material for this purpose. The nucleation and growth of the $\mathrm{Ca}-\mathrm{P}$ phase exhibit the biocompatibility of the fabricated Ti/HA materials as observed for $\mathrm{HA} / \mathrm{Ti} 6 \mathrm{Al} 4 \mathrm{~V}$ composite by Amir et al. [28].

Table 2 Corrosion parameters of materials in saliva at five temperatures

\begin{tabular}{|c|c|c|c|c|c|c|c|}
\hline Material & Temp. $\left({ }^{\circ} \mathrm{C}\right)$ & $E_{\text {corr }}(\mathrm{mV})$ & $i_{\text {corr }}\left(\mu \mathrm{A} / \mathrm{cm}^{2}\right)$ & $-b_{\mathrm{c}}(\mathrm{mV} / \mathrm{dec})$ & $+b_{\mathrm{a}}(\mathrm{mV} / \mathrm{dec})$ & $R_{\mathrm{p}} * 10^{3}\left(\Omega \mathrm{cm}^{2}\right)$ & $\overline{C_{\mathrm{R}}(\mathrm{mpy})}$ \\
\hline \multirow[t]{5}{*}{ Pure Ti } & 10 & -448 & 4.53 & 46.7 & 70.7 & 2.70 & 1.567 \\
\hline & 20 & -449 & 5.66 & 50.2 & 77.9 & 2.34 & 1.958 \\
\hline & 30 & -468 & 9.87 & 64.4 & 70.2 & 1.48 & 3.414 \\
\hline & 40 & -488 & 11.24 & 52.2 & 61.2 & 1.09 & 3.888 \\
\hline & 50 & -489 & 14.10 & 67.1 & 73.7 & 1.08 & 4.878 \\
\hline \multirow[t]{5}{*}{ Ti/HA composite } & 10 & -432 & 2.84 & 33.0 & 50.4 & 3.05 & 0.982 \\
\hline & 20 & -169 & 4.60 & 47.6 & 44.5 & 2.17 & 1.591 \\
\hline & 30 & -630 & 5.11 & 64.4 & 66.0 & 2.77 & 1.768 \\
\hline & 40 & -639 & 5.41 & 38.2 & 37.9 & 1.53 & 1.872 \\
\hline & 50 & -672 & 7.22 & 50.8 & 46.2 & 1.46 & 2.498 \\
\hline \multirow[t]{5}{*}{ Ti/HA FGM } & 10 & -644 & 1.56 & 21.2 & 33.8 & 3.63 & 0.540 \\
\hline & 20 & -604 & 4.27 & 52.7 & 77.9 & 3.20 & 1.477 \\
\hline & 30 & -538 & 4.83 & 43.0 & 56.3 & 2.19 & 1.671 \\
\hline & 40 & -518 & 5.10 & 52.0 & 57.7 & 2.33 & 1.764 \\
\hline & 50 & -462 & 7.11 & 49.2 & 56.0 & 1.60 & 2.460 \\
\hline
\end{tabular}




\section{Conclusion}

Ti/HA materials were fabricated by powder metallurgy method to investigate these materials as restorative in mouth. These materials were Ti/HA as composite with composition $70 \mathrm{Ti} / 30 \mathrm{HA}$ and other was $\mathrm{Ti} / \mathrm{HA}$ as functionally graded material with five layers begin from pure $\mathrm{Ti}$ to pure HA with homogeneity in other layers to get good cohesive among these layers.

The characterization of fabricated was achieved by XRD and SEM, these techniques showed formation many phases between $\mathrm{Ti}$ and $\mathrm{HA}$ such as $\mathrm{Ti}_{4} \mathrm{P}_{3}$ and $\mathrm{Ti}_{2} \mathrm{O}$ in addition to presence of biomaterials of $\mathrm{CaO}$ and TTCP.

Corrosion behavior was tested in saliva at $\mathrm{pH} 4.4$ at five temperatures $10,20,30,40$, and $50{ }^{\circ} \mathrm{C}$ to simulate the temperature of cold and hot food and beverages. The data indicated that Ti/HA materials gave good corrosion resistance compared with pure $\mathrm{Ti}$ due to the phases which were formed between $\mathrm{Ti}$ and HA. Corrosion data were measured by Tafel extrapolation method which include $E_{\text {corr }}, i_{\text {corr }}$, and Tafel slopes, in addition to calculate the corrosion rate and polarization resistance values. Cyclic polarization also tested at $50{ }^{\circ} \mathrm{C}$ to show the pitting corrosion chance. But the pure $\mathrm{Ti}$ and T/HA materials didn't exhibit breakdown potential and hysteresis loop. Biocompatibility also tested for Ti/HA materials using horse serum and they gave good absorbance to culture cells.

\section{References}

1. Avila M, Ojcius DM, Yilmaz O (2009) The oral microbiota: living with a permanent guest. DNA Cell Biol 28:405-411

2. Filoche S, Wong L, Sissons CH (2010) Oral biofilms: emerging concepts in microbial ecology. J Dent Res 89:8-18

3. Hench LL, Ethridge EC (1982) Biomaterials: an interfacial approach. Academic Press, NewYork

4. Adamczyk E, Spiechowicz E (1990) Plaque accumulation on crowns made of various materials. Int J Prosthodont 3:285-291

5. Addy M, Bates JF (1979) Plaque accumulation following the wearing of different types of removable partial dentures. J Oral Rehabil 6:111-117

6. Chan C, Weber H (1986) Plaque retention on teeth restored with full-ceramic crowns: a comparative study. J Prosthet Dent 56:666-671

7. Jameson LM, Malone WF (1982) Crown contours and gingival response. J Prosthet Dent 47:620-624

8. Parkinson CF (1976) Excessive crown contours facilitate endemic plaque niches. J Prosthet Dent 35:424-429

9. Landolt D (2006) Electrochemical and materials aspects of tribocorrosion systems. J Phys D 39(15):3121

10. Yan Y, Neville A, Dowson D (2006) Biotribocorrosion-an appraisal of the time dependence of wear and corrosion interactions: I. The role of corrosion. J Phys D 39:3200-3205

11. Souza JCM, Henriques M, Oliveira R, Teuhels W, Rocha LA, Celis J-P (2010) Biofilms inducing ultra-low friction on titanium. J Dent Res 89(12):1470-1475
12. Souza JCM, Henriques M, Oliveira R, Teuhels W, Celis J-P, Rocha LA (2010) Do oral biofilms influence the biotribocorrosion behavior of titanium? Biofouling 26(4):471-478

13. Souza JCM, Barbosa SL, Ariza E, Celis J-P, Rocha LA (2012) Simultaneous degradation by corrosion and wear of titanium in artificial saliva containing fluorides. Wear 292:82-88

14. Mathew MT, Baraõ VA, Yuan JC, Assunção WG, Sukotjo C, Wimmer MA (2012) What is the role of lipopolysaccharide on the tribocorrosive behavior of titanium? J Mech Behav Biomed Mater 8:71-85

15. Souza JCM, Ponthiaux P, Henriques M, Oliveira R, Teughels W, Celis J-P, Rocha LA (2013) Corrosion behavior of titanium in the presence of Streptococcus mutans. J Dent 41:528-534

16. Souza JCM, Henriques M, Teughels W, Ponthiaux P, Celis J-P, Rocha LA (2015) Wear and corrosion interactions on titanium in oral environment: literature review. J Bio Tribo-Corros 1:13

17. Mondal D, Sarkar SK, Oh I-H, Lee B-T (2011) Comparative study of microstructures and material properties in the vacuum and spark plasma sintered Ti-calcium phosphate composites. Mater Trans 52(7):1436-1442

18. Khalil KA, Sherif E-SM, Almajid AA (2011) Corrosion passivation in simulated body fluid of magnesium/hydroxyapatite nanocomposites sintered by high frequency induction heating. Int J Electrochem Sci 6:6184-6199

19. Balbinotti P, Gemelli E, Buerger G, de Lima SA, de Jesus J, Camargo NHA, Henriques VAR, de Almeida Soares GD (2011) Microstructure development on sintered Ti/HA biocomposites produced by powder metallurgy. Mater Res 14(3):384-393

20. Bermúdez-Reyes B, Puente-Ornelas R, García-Pérez UM, Robledo PZ, Contreras-García ME, Morales-Hernández J, Espinoza-Beltrán FJ (2012) Cyclic polarization and immersion corrosion test on $\mathrm{HA} / \mathrm{ZrO}_{2} / 316 \mathrm{LSS}$ for application on orthopedics prosthesis. Int J Electrochem Sci 7:2028-2035

21. Gemelli E, de Jesus J, Camargo NHA, de Almeida Soares GD, Henriques VAR, Nery F (2012) Microstructural study of a titanium-based biocomposite produced by the powder metallurgy process with $\mathrm{TiH}_{2}$ and nanometric $\beta$-TCP powders. Mater Sci Eng C 32:1011-1015

22. Mondal S, Mondal B, Dey A, Mukhopadhyay SS (2012) Studies on processing and characterization of hydroxyapatite biomaterials from different bio wastes. J Miner Mater Charact Eng 11(1):55-67

23. Rodrigues DC, Valderrama P, Wilson TG Jr, Palmer K, Thomas A, Sridhar S, Adapalli A, Burbano M, Wadhwani C (2013) Titanium corrosion mechanisms in the oral environment: a retrieval study. Materials 6:5258-5274

24. Singh T, Bala N, Singh L (2013) Characterization and corrosion behavior of hydroxyapatite and hydroxyapatite/titania bond coating on 316L SS substrate in simulated body fluid. Int J Surf Eng Mater Technol 3(1):27

25. Major L, Lackner JM, Kot M, Janusz M, Major B (2014) Contribution of TiN/Ti/a-C: $\mathrm{H}$ multilayers architecture to biological and mechanical properties. Bull Pol Acad Sci Tech Sci 62(3):565-570

26. Reindl A, Borowsky R, Hein SB, Geis-Gerstorfer J, Imgrund P, Petzoldt F (2014) Degradation behavior of novel Fe/ß-TCP composites produced by powder injection molding for cortical bone replacement. J Mater Sci 49:8234-8243

27. Song H-J, Han M-K, Jeong H-G, Lee Y-T, Park Y-J (2014) Microstructure analysis of Ti-xPt alloys and the effect of Pt content on the mechanical properties and corrosion behavior of $\mathrm{Ti}$ alloys. Materials 7:3990-4000

28. Arifin A, Sulong AB, Muhamad N, Syarif J, Raml MI (2015) Powder injection molding of HA/Ti6Al4V composite using palm stearin as based binder for implant material. Mater Des 65:1028-1034 
29. Porcayo-Calderon J, Casales-Diaz M, Salinas-Bravo VM, Martinez-Gomez L (2015) Corrosion performance of Fe-Cr-Ni alloys in artificial saliva and mouthwash solution, Bioinorg Chem Appl

30. Geis Gerstorfer J, Weber H (1985) Effect of potassium thio cyanate on corrosion behavior of non- precious metal dental alloys. Dtsch Zahnärztl 40:87-91

31. Zhang BB, Zheng YF, Liu Y (2009) Effect of silver on the corrosion behavior of Ti-Ag alloys in artificial saliva solutions. Dent Mater 25:672-677

32. Marceloa TM, Livramentoa V, de Oliveira MV, Carvalho MH (2006) Microstructural characterization and interactions in Ti and $\mathrm{TiH}_{2}$-hydroxyapatite vacuum sintered composites. Mater Res 9(1):65-71

33. Thian ES, Loh NH, Khor KA, Tor SB (2002) Microstructures and mechanical properties of powder injection molded Ti-6Al-4V HA powder. Biomaterials 23:2927-2938

34. Pourbaix M (1963) Atlas d "Equilibres Electrochimiques a 25 C". Gauthier Villars, Paris

35. Al-Khazraji KK, Ataiwi AH, Majed RA, Abdulhameed ZN (2012) Effect of some anti-inflammatory drugs on the corrosion behavior of implant biomaterials in human body fluid. Eng Tech $\mathbf{J}$ 30(6):959-973
36. Majed RA, Abdulmajeed MH, Ibrahem SI, Abdul Maged SA (2014) Effect of (50\% isopropanol-30\%methanol-17\%xylene) mixture on corrosion behavior of pure $\mathrm{Al}$ and its alloys in simulated fuel. Eng Tech J 32(6):1380-1389

37. Majed RA (2013) Galvanic corrosion of dental alloys and amalgam in artificial saliva containing citric acid. Eng Tech $\mathbf{J}$ 31(12):2299-2310

38. Muhsin SA (2015) Ph.D. Thesis, Investigation the effect of Ti/ HA FGM as an alternative material for dental implant, Department of Materials Eng.-University of Technology/Iraq

39. Bidhendi HRA, Pouranvari M (2011) Corrosion study of metallic biomaterials in simulated body fluid. Metalurgija-MJoM 17(1):13-22

40. Assis SL, Wolynec S, Costa I (2006) Corrosion characterization of titanium alloys by electrochemical techniques. Electrochim Acta 51:1815-1819

41. Marcus P, Baroux B, Keddam M (eds) (1994) Modification of passive film. European Federation of Corrosion Publication, The Institute of Materials, London 